\title{
ANALISIS KEBUTUHAN PETUNJUK PRAKTIKUM BERBASIS KETERAMPILAN PROSES SAINS UNTUK MENCAPAI KEMAMPUAN MERANCANG EKSPERIMEN
}

\section{NEED ANALYSIS OF SCIENCE PROCESS SKILLS BASED PRACTICAL INSTRUCTION TO ACHIEVE EXPERIMENT DESIGN ABILITY}

\author{
Veri Firmansyah, Fitriah Khoirunnisa*, Friska Septiani Silitonga \\ Program Studi Pendidikan Kimia, Universitas Maritim Raja Ali Haji \\ Jl. Politeknik Senggarang, Tanjungpinang, Kepulauan Riau. Kode Pos: 29115 \\ *e-mail korespondensi: fitriahk@umrah.ac.id
}

\begin{abstract}
Abstrak
Penelitian ini bertujuan menganalisis kebutuhan petunjuk praktikum berbasis Keterampilan Proses Sains (KPS) untuk mencapai kemampuan merancang eksperimen pada materi kalor reaksi. Penelitian dilakukan terhadap peserta didik kelas XI SMA Negeri 2 Kota Tanjungpinang. Variabel penelitian mencakup analisis kebutuhan bahan ajar dan analisis kesesuaian Kompetensi Inti (KI) dan Kompetensi Dasar (KD). Jenis penelitian yang dilakukan adalah penelitian deskriptif kualitatif. Tahapan pertama dalam penelitian ini adalah menganalisis kebutuhan bahan ajar dengan cara membandingkan dua petunjuk praktikum yang selama ini telah digunakan di sekolah tersebut, ditinjau dari aspek struktur format penulisan, aspek kreativitas, dan aspek keterampilan proses sains yang terdapat dalam petunjuk praktikum, sehingga didapatkan kesimpulan bahwa petunjuk praktikum yang selama ini digunakan tidak memberikan kesempatan kepada peserta didiknya untuk merancang eksperimen yang telah ditentukan. Tahapan kedua yaitu menganalisis kesesuaian kompetensi inti dan kompetensi dasar, yang bertujuan untuk menentukan indikator pencapaian kompetensi (IPK) yang akan menjadi acuan dalam mengembangkan petunjuk praktikum berbasis keterampilan proses sains. Dari kedua tahapan yang telah dilakukan maka dapat disimpulkan bahwa peserta didik memerlukan petunjuk praktikum yang mampu mengonstruksi pikiran dan mengaktifkan kinerja mereka, sehingga pendekatan Keterampilan Proses Sains menjadi pilihan dalam mengembangkan petunjuk praktikum yang sesuai dengan karakteristik kurikulum 2013.
\end{abstract}

Kata kunci: petunjuk praktikum, keterampilan proses sains, kalor reaksi

\begin{abstract}
This research aims to analyze the needs of Science Process Skills based Practical Instruction to achieve the ability to design experiments on the calor of reaction. This research was done to the students of class XI SMA Negeri 2 Tanjungpinang City. Research variable includes the analysis of the needs of the learning materials and analysis of the suitability of the Core Competence and Basic Competence. The type of research conducted is descriptive qualitative research. The first stages in this research is to analyze the needs of learning materials by comparing two practical instruction that had been implementing in the school, from the aspects of the structure of writing format, creativity, and science process skills embedded in practical instruction. The conclusion of this research that current practical instructions does not give an opportunity to the participants to design determined experiments. The second stage, namely analyzing the suitability of core competence and basic competence, which aims to determine the indicators of achievement of the competencies (GPA) which will be a reference in developing science process skills based practical instruction. Of the two stages that has been done then it can be concluded that learners need practical instruction to construct thinking and and their performance, so the science process skills approach is an option in developing practical instruction suitable for the characteristics of the curriculum of 2013.
\end{abstract}

Keywords: practical instruction, science process skills, calor of reaction 


\section{PENDAHULUAN}

Salah satu tujuan dari pendidikan nasional pada pasal 3 yang termaktub dalam UU RI No 20 Tahun 2003 tentang Sistem Pendidikan Nasional adalah mengembangkan kemampuan peserta didik dalam memiliki kecakapan, kreativitas dan sifat yang mandiri. Namun, fakta di lapangan belum sepenuhnya peserta didik memiliki kompetensi yang dimaksud. Berdasarkan hasil wawancara kepada guru kimia di SMA Negeri 2 Tanjungpinang mengenai masalah yang dihadapi peserta didik selama proses pembelajaran, terutama pada materi yang memerlukan aktifitas dan kreatifitas yang tinggi, diperoleh informasi bahwa metode pembelajaran pada mata pelajaran kimia masih menggunakan metode diskusi dan pengerjaan latihan soal.

Begitu halnya dengan pelaksanaan praktikum, dimana bahan ajar yang digunakan masih berupa petunjuk praktikum standar yang hanya menginstruksikan peserta didik untuk melakukan cara kerja yang sudah tepat tertulis di dalam petunjuk praktikum tersebut. Sehingga keberadaan petunjuk praktikum untuk materimateri yang mengukur psikomotorik peserta didik masih belum mampu mencapai kriteria mengaktifkan ide dan kreatifitas peserta didik, serta belum dapat mengembangkan keterampilan proses sains yang dimilikinya. Hal tersebut tentunya secara tidak langsung dapat menghilangkan semangat peserta didik dalam berkreasi dan beraktifitas selama proses pembelajaran berlangsung. Seyogyanya peserta didik memerlukan bahan ajar yang melibatkan mereka secara langsung dalam proses pembelajarannya sehingga menunjang kemampuan berpikir kritis dan kemampuan mengonstruksi pengetahuan yang mereka miliki, sejalan dengan penelitian Khoirunnisa (2017).

Kemampuan peserta didik tersebut dapat diasah dengan pendekatan Keterampilan Proses Sains (KPS), terutama saat proses pembelajaran memerlukan metode eksperimen yang dibantu dengan adanya petunjuk praktikum. Petunjuk praktikum yang dibutuhkan tentunya yang tidak hanya menampilkan cara kerja pasti yang harus diikuti peserta didiknya, namun juga harus bersifat konstruktif sehingga peserta didik mampu mengeksplorasi kompetensi dan pemahamannya terkait kegiatan praktikum yang akan dijalankan.

Keterampilan Proses Sains (KPS) sangat berpengaruh besar bagi kinerja dan hasil belajar peserta didik, hal tersebut sesuai dengan penelitian Hartono, dkk.(2014), Marpaung, dkk.
(2017), dan Zulaiha (2014). Apalagi dalam pembelajaran kimia, sebenarnya lebih menekankan pada KPS yang menuntut peserta didik dalam menentukan fakta, membangun konsep, dan mengembangkan sikap ilmiah (Hamalik, 2013).

Berdasarkan permasalahan terkait kurangnya bahan ajar yang mampu mengasah Keterampilan Proses Sains peserta didik di salah satu sekolah di Tanjungpinang, terutama saat pembelajaran memasuki proses kegiatan praktikum, maka penelitian ini akan menganalisis secara mendalam kebutuhan petunjuk praktikum serta menganalisis kesesuaian kompetensi inti (KI) dan kompetensi dasar (KD) berdasarkan silabus kimia dalam kurikulum 2013. Sehingga hasil analisis akan dapat digunakan untuk mengembangkan petunjuk praktikum yang sesuai dengan kriteria Keterampilan Proses Sains.

\section{METODE PENELITIAN}

Penelitian ini menggunakan pendekatan deskriptif kualitatif, yaitu menjabarkan secara deskriptif hasil analisis yang dilakukan. Adapun tahapannya sebagai berikut:

a. Tahap wawancara. Wawancara dilakukan kepada guru mata pelajaran Kimia di tempat pelaksanaan penelitian (SMA Negeri 2 Tanjungpinang), untuk mendapatkan data berupa penggunaan petunjuk praktikum yang selama ini digunakan dan harapan untuk perbaikan.

b. Tahap menganalisis petunjuk praktikum. Analisis petunjuk praktikum dilakukan terhadap dua buah petunjuk praktikum yang selama ini telah digunakan di sekolah tersebut. Lalu melakukan penskoran terhadap petunjuk praktikum tersebut, apakah sudah sesuai dengan kriteris Keterampilan Proses Sains atau belum.

c. Tahap menganalisis kesesuaian KI dan KD. Bertujuan untuk menyesuaikan antara KI dan KD yang digunakan dalam Kurikulum 2013 dengan komponen Keterampilan Proses Sains yang diintegrasikan ke dalam petunjuk praktikum yang akan dikembangkan.

Dalam menentukan hasil analisis petunjuk praktikum yang digunakan, merujuk pada kriteria validitas petunjuk praktikum pada Tabel 1 berikut 
Tabel 1. Kriteria Analisis Petunjuk Praktikum (Puspita, 2017)

\begin{tabular}{cll}
\hline $\begin{array}{c}\text { Persentase } \\
(\boldsymbol{\%})\end{array}$ & \multicolumn{1}{c}{ Kriteria } & Keterangan \\
\hline $80-100$ & Sangat baik & Tidak revisi \\
$66-79$ & Baik & Tidak revisi \\
$56-65$ & Cukup baik & Tidak revisi \\
$40-55$ & Kurang baik & Revisi \\
$30-39$ & Sangat tidak baik & Revisi \\
\hline
\end{tabular}

\section{HASIL DAN PEMBAHASAN}

Analisis yang dilakukan mencakup 3 tahapan, yaitu analisis hasil wawancara terhadap penggunaan petunjuk praktikum, analisis petunjuk praktikum berdasarkan kriteria Keterampilan Proses Sains, dan analisis kesesuaian Kompetensi Inti (KI) dan Kompetensi Dasar (KD). Berikut pemaparan hasil analisis:

1) Analisis Hasil Wawancara Penggunaan Petunjuk Praktikum

Hasil wawancara kepada guru Kimia terkait petunjuk praktikum yang digunakan di salah satu sekolah di Kota Tanjungpinang, didapatkan bahwa petunjuk praktikum yang selama ini digunakan adalah petunjuk praktikum yang memuat cara kerja yang sudah baku, sehingga para peserta didik hanya mengikuti langkah-langkah kerjanya saja tanpa dituntut memikirkan bagaimana dan mengapa hasil praktikum tersebut didapatkan, mereka hanya difokuskan pada pengisian lembar praktikum sesuai cara kerja yang diberikan, tanpa diberikan kesempatan mencari alternatif cara kerja yang sesuai dengan tema praktikum. Didapatkan informasi bahwa memang dibutuhkan petunjuk praktikum yang mampu mengasah kreatifitas peserta didik, salah satunya dengan merujuk kriteria Keterampilan Proses Sains. Keterampilan Proses Sains menjadi rujukan dalam pembelajaran, karena dianggap mampu memecahkan masalah dalam pembelajaran dan juga berdasarkan hasil penelitian Abungu dkk (2014) yang menyatakan bahwa prestasi belajar peserta didik dipengaruhi oleh penerapan Keterampilan Proses Sains dalam pembelajarannya. Namun, sejauh ini pengembangan petunjuk praktikum tersebut mengalami kendala, baik dari aspek finansial hingga keterbatasan pemahaman dalam proses mengembangkannya.
2) Analisis Kebutuhan Petunjuk Praktikum Berbasis Keterampilan Proses Sains

Tahapan pertama, analisis petunjuk praktikum yang selama ini digunakan pada materi kalor reaksi di sekolah tempat pelaksanaan penelitian. Petunjuk praktikum yang dianalisis sebanyak dua buah. Analisis petunjuk praktikum meliputi aspek struktur petunjuk praktikum secara umum, kreatifitas siswa, dan keterampilan proses sains (Fauzi, 2015) dan kriteria skor per indikator merujuk pada Puspita (2017). Hasil yang didapat menunjukkan bahwa petunjuk praktikum yang selama ini digunakan belum sesuai dengan struktur petunjuk praktikum yang terdiri dari beberapa indikator, seperti yang dijabarkan dalam Tabel 2 berikut

Tabel 2. Hasil Analisis Petunjuk Praktikum pada Aspek Struktur secara Umum

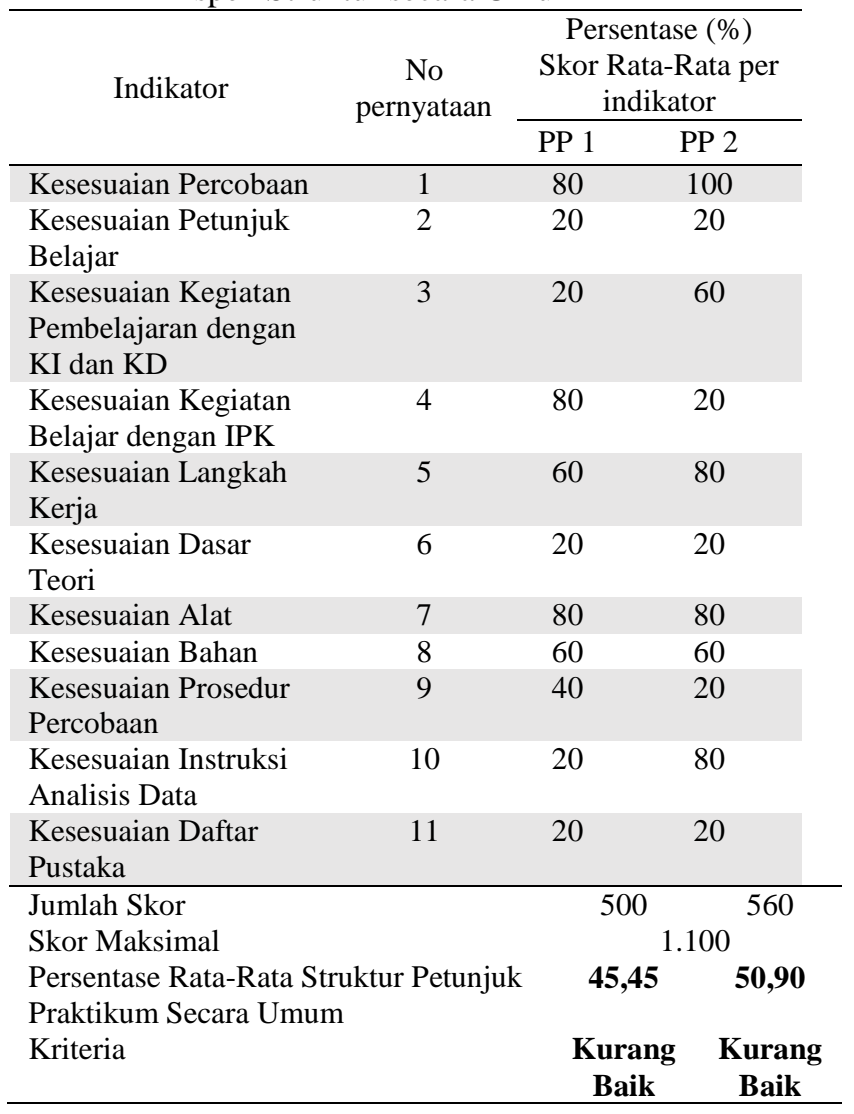

Hasil persentase rata-rata penggunaan petunjuk praktikum pada aspek struktur petunjuk praktikum secara umum terhadap dua buah petunjuk praktikum menunjukkan kriteria yang kurang baik dengan skor masing-masing $45,45 \%$ dan $50,90 \%$. Sehingga dibutuhkan revisi petunjuk praktikum agar sesuai dengan kriteria struktur petunjuk praktikum secara umum. 
Aspek kedua yang dianalisis pada petunjuk praktikum yang selama ini digunakan adalah aspek kreatifitas. Aspek ini memuat indikator-indikator yang berkaitan dengan penyajian petunjuk praktikum yang digunakan. Sehingga dapat terlihat apakah petunjuk praktikum tersebut memicu kreatifitas peserta didik dalam pelaksanaannya ataukah tidak. Berdasarkan hasil analisis pada aspek ini, maka didapatkan hasil rata-rata sebesar 30\% untuk masing-masing petunjuk praktikum yang masuk ke dalam kriteria sangat tidak baik, yang berarti bahwa petunjuk praktikum yang selama ini digunakan samasekali belum menuntut kreatifitas siswa selama melakukan praktikum.

Tabel 3. Hasil Analisis Petunjuk Praktikum pada Aspek Kreatifitas

\begin{tabular}{|c|c|c|c|c|}
\hline \multirow[t]{2}{*}{ Aspek } & \multirow[t]{2}{*}{ Indikator } & \multirow[t]{2}{*}{$\begin{array}{c}\text { No } \\
\text { pernyataan }\end{array}$} & \multicolumn{2}{|c|}{$\begin{array}{l}\text { Persentase (\%) } \\
\text { Skor Rata-Rata per } \\
\quad \text { indikator }\end{array}$} \\
\hline & & & PP 1 & PP 2 \\
\hline \multirow[t]{4}{*}{ Kreatifitas } & $\begin{array}{l}\text { Penentuan } \\
\text { Tujuan } \\
\text { Percobaan }\end{array}$ & 12 & 20 & 20 \\
\hline & $\begin{array}{l}\text { Penentuan } \\
\text { Alat Dan } \\
\text { Bahan } \\
\text { Percobaan }\end{array}$ & 13 & 20 & 20 \\
\hline & $\begin{array}{l}\text { Penentuan } \\
\text { Prosedur } \\
\text { Percobaan }\end{array}$ & 14 & 20 & 20 \\
\hline & $\begin{array}{l}\text { Penentuan } \\
\text { Hasil } \\
\text { Pegamatan }\end{array}$ & 15 & 60 & 60 \\
\hline \multirow{4}{*}{\multicolumn{3}{|c|}{$\begin{array}{l}\text { Jumlah Skor } \\
\text { Skor Maksimal } \\
\text { Persentase Rata-Rata Kreatifitas } \\
\text { Kriteria }\end{array}$}} & 120 & 120 \\
\hline & & & \multicolumn{2}{|c|}{400} \\
\hline & & & 30 & 30 \\
\hline & & & $\begin{array}{c}\text { Sangat } \\
\text { Tidak } \\
\text { Baik }\end{array}$ & $\begin{array}{c}\text { Sangat } \\
\text { Tidak } \\
\text { Baik }\end{array}$ \\
\hline
\end{tabular}

Berdasarkan hasil tersebut, maka dibutuhkan revisi petunjuk praktikum yang mampu mengasah kreatifitas peserta didik, yaitu dengan mengintegrasikan aspek Keterampilan Proses Sains. Kreatifitas peserta didik sangat dibutuhkan dalam proses pembelajaran karena dengan adanya kreatifitas maka akan membantu peserta didik memahami apa yang sedang dilakukannya. Dan keterampilan proses sains dapat membantu membangun pemahaman peserta didik terhadap materi pelajaran yang sedang mereka terima (Safaah, dkk., 2016).
Aspek ketiga yang dianalisis yaitu aspek keterampilan proses sains yang terkandung dalam petunjuk praktikum yang selama ini telah digunakan untuk materi kalor reaksi. Hasil analisis menunjukkan bahwa keterampilan proses sains pada kedua petunjuk praktikum tersebut masih kurang baik dalam menampilkan keterampilan proses sains untuk merancang eksperimen pada materi kalor reaksi dengan persentase petunjuk praktikum I sebesar 48,57\% dan petunjuk praktikum II sebesar $40 \%$.

Tabel 4. Hasil Analisis Petunjuk Praktikum pada Aspek Keterampilan Proses Sains

\begin{tabular}{|c|c|c|c|c|}
\hline \multirow[t]{2}{*}{ Aspek } & \multirow[t]{2}{*}{ Indikator } & \multirow[t]{2}{*}{$\begin{array}{l}\text { No } \\
\text { pernyata } \\
\text { an }\end{array}$} & \multicolumn{2}{|c|}{$\begin{array}{l}\text { Persentase }(\%) \\
\text { Skor Rata-Rata } \\
\text { per indikator }\end{array}$} \\
\hline & & & PP 1 & PP 2 \\
\hline \multirow{7}{*}{$\begin{array}{l}\text { Keterampil } \\
\text { an Proses } \\
\text { Sains }\end{array}$} & $\begin{array}{l}\text { Kegiatan } \\
\text { Mengamati }\end{array}$ & 16 & 20 & 20 \\
\hline & $\begin{array}{l}\text { Kegiatan } \\
\text { Menggolongkan }\end{array}$ & 17 & 20 & 20 \\
\hline & $\begin{array}{l}\text { Kegiatan } \\
\text { Menafsirkan }\end{array}$ & 18 & 60 & 80 \\
\hline & $\begin{array}{l}\text { Kegiatan } \\
\text { Meramalkan }\end{array}$ & 19 & 20 & 40 \\
\hline & $\begin{array}{l}\text { Kegiatan } \\
\text { Menerapkan }\end{array}$ & 20 & 80 & 60 \\
\hline & $\begin{array}{l}\text { Kegiatan } \\
\text { Merencanakan }\end{array}$ & 21 & 40 & 20 \\
\hline & $\begin{array}{l}\text { Kegiatan } \\
\text { Mengkomunikasi } \\
\text { kan }\end{array}$ & 22 & 100 & 40 \\
\hline \multirow{4}{*}{\multicolumn{2}{|c|}{$\begin{array}{l}\text { Jumlah Skor } \\
\text { Skor Maksimal } \\
\text { Persentase Rata-Rata Kreatifitas } \\
\text { Kriteria }\end{array}$}} & & 340 & 280 \\
\hline & & & \multicolumn{2}{|c|}{700} \\
\hline & & & 48,57 & 40 \\
\hline & & & $\begin{array}{c}\text { Kurang } \\
\text { Baik }\end{array}$ & $\begin{array}{c}\text { Kurang } \\
\text { Baik }\end{array}$ \\
\hline
\end{tabular}

3) Analisis kesesuaian Kompetensi Inti (KI) dan Kompetensi Dasar (KD)

Tahapan berikutnya, yaitu analisis kesesuaian KI dan KD yang dilakukan guna menentukan Indikator Pencapaian Kompetensi (IPK) yang akan diimplementasikan ke dalam petunjuk praktikum yang akan dikembangkan dengan berbasis keterampilan proses sains dalam merancang eksperimen pada materi kalor reaksi. Maka, berdasarkan hasil analisis KI dan $\mathrm{KD}$, terdapat dua buah indikator yang akan menjadi acuan dalam mengembangkan petunjuk praktikum berbasis keterampilan proses sains. Adapun rincian hasil analisis kesesuaian KI dan KD sehingga menghasilkan IPK terdapat pada Tabel 5 berikut 
Tabel 5. Analisis Kesesuaian Kompetensi Inti (KI) dan Kompetensi Dasar (KD)

\begin{tabular}{|c|c|c|c|}
\hline $\begin{array}{l}\text { Kompetensi } \\
\text { Inti (KI 4) }\end{array}$ & $\begin{array}{c}\text { Kompetensi } \\
\text { Dasar } \\
(\text { KD 4.4) }\end{array}$ & $\begin{array}{c}\text { Indikator } \\
\text { Pencapaian } \\
\text { Kompetensi } \\
\text { (IPK) }\end{array}$ & Materi \\
\hline $\begin{array}{l}\text { Mengolah, } \\
\text { menalar } \\
\text { menyaji dan } \\
\text { mencipta } \\
\text { dalam ranah } \\
\text { konkret dan } \\
\text { ranah abstrak } \\
\text { terkait dengan } \\
\text { pengembang- } \\
\text { an dari yang } \\
\text { dipelajarinya } \\
\text { disekolah } \\
\text { secara mandiri } \\
\text { serta bertindak } \\
\text { secara efektif } \\
\text { dan kreatif dan } \\
\text { mampu } \\
\text { mengguna-kan } \\
\text { metode sesuai } \\
\text { kaidah } \\
\text { keilmuan. }\end{array}$ & $\begin{array}{l}\text { Menyimpulka } \\
\mathrm{n} \text { hasil } \\
\text { analisis data } \\
\text { percobaan } \\
\text { termokimia } \\
\text { pada tekanan } \\
\text { tetap }\end{array}$ & $\begin{array}{l}\text { 4.4.1. } \\
\text { Melakukan } \\
\text { percobaan } \\
\text { penentuan } \\
\text { kalor reaksi } \\
\text { pada tekanan } \\
\text { tetap dengan } \\
\text { mengguna- } \\
\text { kan } \\
\text { kalorimetri } \\
\text { sederhana } \\
\text { 4.4.2. Mampu } \\
\text { menganalisis } \\
\text { hasil } \\
\text { percobaan } \\
\text { penentuan } \\
\text { kalor reaksi } \\
\text { pada tekanan } \\
\text { tetap dengan } \\
\text { mengguna- } \\
\text { kan } \\
\text { kalorimetri } \\
\text { sederhana }\end{array}$ & $\begin{array}{l}\text { Penentuan } \\
\text { perubahan } \\
\text { entalpi } \\
\text { reaksi } \\
\text { kalorimetri }\end{array}$ \\
\hline
\end{tabular}

\section{KESIMPULAN}

Berdasarkan hasil penelitian dan pembahasan yang telah dijabarkan, maka disimpulkan bahwa kedua petunjuk praktikum kimia yang selama ini digunakan di SMA Negeri 2 Tanjungpinang belum memenuhi kriteria mengaktifkan peserta didik, sehingga tidak memberikan kesempatan kepada peserta didik untuk merancang eksperimen terutama pada materi kalor reaksi. Sehingga diperlukan penelitian pengembangan petunjuk praktikum berbasis Keterampilan Proses Sains lebih lanjut, terutama pada materi kalor reaksi. Adapun implikasi penelitian ini yaitu dengan direvisinya petunjuk praktikum agar sesuai dengan kriteria keterampilan proses sains, maka akan mengasah kreatifitas dan keterampilan merancang ekseperimen peserta didik, terutama pada materi Kalor Reaksi.

\section{DAFTAR RUJUKAN}

Abungu, H. E., Okere, M. I. O., dan Wachanga, S. W. (2014). The Effect of Science Process Skills Teaching Approach on Secondary School Students' Achievement in Chemistry in Nyando District, Kenya. Journal of Educational and Social Research, 4 (6), pp. 359-372. MCSER Publishing. Rome-Italy.

Fauzi. M., M. (2015). Pengembangan Lembar Kerja Siswa Berbasis Keterampilan Proses Sains Pada Konsep Larutan Penyangga. Skripsi. UIN Syarif Hidayatullah, Jakarta.
Hamalik, O. 2013. Kurikulum dan Pembelajaran Edisi 1. Bumi Aksara, Jakarta.

Hartono, Z., dan Rachman, I. (2014). Pengembangan Buku Panduan Praktikum Kimia Hidrokarbon Berbasis Keterampilan Proses Sains di SMA. Jurnal Pendidikan Kimia, 1 (1), pp. 87-93.

Khoirunnisa, F., dan Sabekti, A.W. (2017). Analisis Kebutuhan Pengembangan Modul Ajar Strategi Pembelajaran Kimia dengan Pendekatan Daur Belajar Enam Fase. Prosiding Seminar Nasional Kimia UNY. FMIPA UNY, Yogyakarta, 14 Oktober 2017: hlm. 63-66.

Marpaung dan Meida, E. (2017). Pengembangan Penuntun Praktikum Stoikiometri Inovatif Sesuai Kurikulum 2013 Berbasis Keterampilan Proses Sains. Masters Tesis. Universitas Medan.

Puspita, A. 2017. Pengembangan Media Booklet Pada Materi Sistem Imun Terhadap Hasil Belajar Siswa Kelas XI SMAN 8 Pontianak. Jurnal Bioeducation. 4 (1), pp. 64-73.

Safaah, E.S., Muslim, M., dan Liliawati, W. (2016). Teaching Science Process Skills by Using the 5-Stage Learning Cycle in Junior High School. Journal of Physic, 895. IOP Publishing.

Zulaiha. (2014). Pengembangan Buku Panduan Praktikum Kimia Hidrokarbon Berbasis Keterampilan Proses Sains di SMA. Jurnal Pendidikan Kimia, 1 (1), pp. 87-93. 